\title{
KINETIC PARAMETERS OF INULINASE AND LEVANASE ACTIVITY OF RAM RUMEN BACTERIA UNDER THE INFLUENCE OF CLINOPTILOLITE
}

\author{
M. Y. Sabat ${ }^{1}$, R. Ya. Iskra ${ }^{2}$ \\ mariana.sabat@gmail.com
}

${ }^{1}$ Lviv National University of Veterinary Medicine

and Biotechnologies named after S. Z. Gzhytskyj,

50 Pekarska str., Lviv 79010, Ukraine

${ }^{2}$ Institute of animal biology NAAS,

38 Stus str., Lviv 79034, Ukraine

Fructans are a group of fructose polymers, synthesized by plants and microorganisms. Plant fructans (inulin and flein) have a relatively low degree of polymerization (to 40), and bacterial (levan) - large (up to 1.000.000). Microscopic fungi, yeast and a lot of bacteria, in particular the representatives of the rumen microflora, are capable of producing inulinase, which breaks down a variety of fructane, and levanase, which hydrolyzes the main chain of levan.

We determined the levanase activity of extracellular bacteria extract of rumen in rams which were fed with natural fructan and sorbent of clinoptilolite during twenty one days. Kinetic analysis of the inulinase fructan hydrolysis reaction and levanase was performed in a standard incubation environment modified by the physicalchemical parameters (temperature, $\mathrm{pH}$ ) and substrates content. We determined the Michaelis constant for the substrate saturation conditions (inulin and levan) and a maximum reaction speed of hydrolysis by the method of Lainuiver-Berk. Temperature $\left(37^{\circ} \mathrm{C}\right)$ and pH optimum (4-6) inulinase and levanase activity was defined.

We have found out that with the increasing concentration of inulin and levan from 0.1 to 0.4-0.5 $\mathrm{mM}$ the enzymatic activities of fructanhydrolase monotonously increased to their maximum values and thereafter they were maintained at a constant level. It was found that inulin was metabolized with inulinase at greater speed compared to levan under conditions of saturation with the substrate. Levanase hydrolyzed levan but was inactive concerning inulin. In the presence of clinoptilolite the affinity of both hydrolasesdue to the substrates was increased.

Keywords: FRUCTANS, INULIN, LEVAN, CLINOPTILOLITE, RUMEN MICROBIAL METABOLISM

\section{КІНЕТИЧНІ ПАРАМЕТРИ ІНУЛІНАЗНОЇ ТА ЛЕВАНАЗНОЇ АКТИВНОСТІ БАКТЕРІЙ РУБЦЯ БАРАНІВ ЗА ВПЛИВУ КЛІНОПТИЛОЛІТУ}

\author{
М. Я. Сабат ${ }^{1}$, Р. Я. Іскра \\ mariana.sabat@gmail.com
}
${ }^{1}$ Львівський національний університет ветеринарної медицини
та біотехнологій імені С. 3. Гжицького,
вул. Пекарська, 50, м. Львів 79010, Україна
${ }^{2}$ Інститут біології тварин НААН,
вул. Стуса, 38, м. Львів, 79034, Україна

Фруктани є групою полімерів фруктози, які синтезуються рослинами і мікроорганізмами. Фруктани рослин (інулін і флеїн) мають відносно низький ступінь полімеризаиії (до 40), а бактеріальні (леван) високий (до 1000000). Мікроскопічні гриби, дріжджі і деякі бактерії, зокрема представники мікрофлори рубия, здатні виробляти інулінази, щьо руйнують різноманітні фруктани, та леванази, які гідролізують основний ланщюг левану.

Проведено визначення активності інулінази та леванази у безклітинному екстракті бактерій рубия баранів, яким упродовж двадияти однісї доби згодовували природні фруктани та сорбент кліноптилоліт. Виконано кінетичний аналіз реакції гідролізу фруктанів інуліназою та леваназою, щуо проводили у стандартному середовищі інкубування, яке модифікували за фізико-хімічними параметрами (температура, рН) та вмістом субстратів. Визначали константу Міхаеліса за умов насичення субстратом 
(інуліном та леваном) та максимальну швидкість реакиї̈ гідролізу методом Лайнуївера-Берка. Було визначено температурний $\left(37^{\circ} \mathrm{C}\right)$ та рН-оптимум (4-6) активності інулінази та леванази.

Встановлено, що зі збільшенням концентрації як інуліну, так і левану від 0,1 до 0,4-0,5 мМ відбувалося монотонне наростання ензиматичних фруктангідролазних активностей до їх максимальних значень, після чого вони підтримувалися на незмінному рівні. Було виявлено, щсо інулін метаболізувався інуліназою з більшою швидкістю, порівняно з леваном, за умов насичення субстратом. Леваназа гідролізувала леван, проте була неактивною щодо інуліну. За наявності кліноптилоліту спорідненість обох гідролаз до субстратів підвищувалася.

Ключові слова: ФРУКТАНИ, ІНУЛІН, ЛЕВАН, КЛІНОПТИЛОЛІТ, РУБЦЕВИЙ МІКРОБНИЙ МЕТАБОЛІЗМ

\title{
КИНЕТИЧЕСКИЕ ПАРАМЕТРЫ ИНУЛИНАЗНОЙ И ЛЕВАНАЗНОЙ АКТИВНОСТИ БАКТЕРИЙ РУБЦА БАРАНОВ ПОСЛЕ ВОЗДЕЙСТВИЯ КЛИНОПТИЛОЛИТА
}

\author{
М. Я. Сабат ${ }^{1}$, Р. Я. Искра ${ }^{2}$ \\ mariana.sabat@gmail.com
}

${ }^{1}$ Львовский национальный университет ветеринарной медицины

и биотехнологий имени С. З. Гжицкого,

ул. Пекарская, 50, г. Львов, 79010, Украина

${ }^{2}$ Институт биологии животных НААН,

ул. Стуса, 38, г. Львов, 79034, Украина

Фруктаны являются группой полимеров фруктозы, которые синтезируются растениями и микроорганизмами. Фруктаны растений (инулин и флеин) имеют относительно низкую степень полимеризации (до 40), а бактериальные (ливан) - высокую (до 1000000). Микроскопические грибы, дрожжи и некоторые бактерии, в том числе представители микрофлоры рубиа, способны производить инулиназы, разрушающие различные фруктаны, и леваназы, которые гидролизируют основную иепь левана.

Проведено определение активности инулиназы и леваназы в бесклеточном экстракте бактерий рубиа баранов, которым в течение двадиати суток скармливали природные фруктаны и сорбент клиноптилолит. Выполнен кинетический анализ реакции гидролиза фруктана инулиназой и леваназой, проведенные в стандартной среде инкубации, которую модифичировали по физико-химическим параметрам (температура, рН) и содержанию субстратов. Определяли константу Михаэлиса в условиях насыщения субстратом (инулином и леваном) и максимальную скорость реакиии гидролиза методом Лайнуивера-Берка. Было определено температурный $\left(37^{\circ} \mathrm{C}\right)$ и $\mathrm{pH}$-оптимум (4-6) активности инулиназы и леваназы.

Установлено, что с увеличением концентрации как инулина, так и левана от 0,1 до 0,4-0,5 ммоль происходило монотонное нарастание ферментативных фруктангидролазных активностей до их максимальных значений, после чего они поддерживались на неизменном уровне. Было обнаружено, что инулин метаболизировалса инулиназой с большей скоростью по сравнению с леваном в условиях насыщения субстратом. Леваназа гидролизировала ливан, однако, была неактивной к инулину. При наличии клиноптилолита родство обоих гидролаз к субстратам повышалось.

\section{Ключевые слова: ФРУКТАНЫ, ИНУЛИН, ЛЕВАН, КЛИНОПТИЛОЛИТ, РУБЦЕВОЙ МИКРОБНЫЙ МЕТАБОЛИЗМ}

Fructans are a group of fructose polymers containing one of two fructosile-fructose and are synthesized by plants and microorganisms [1]. Plant fructans (inulin and flein of $\beta(1 \rightarrow 2)$ - connections) have a relatively low degree of polymerization (to 40), and bacterial (levan of $\beta(2 \rightarrow 6)$ - connections) - large (up to 1.000.000)
[2-4]. Microscopic fungi, yeast and a lot of bacteria, in particular those that are the representatives of the rumen microflora, are capable of producing inulinase (2,1- $\beta$-fructozane in fructanhydrolase), which breaks down a variety of fructane and levanase (2,6- $\beta$-D fructane fructanhydrolase), which hydrolyzes the main chain of levan. To assimilate 
mentioned fructans of ruminants body, first are split by microbial biomass, later they can be absorbed in the digestive tract.

Enzymes that hydrolyze different fructans belong to $\beta$-fructofuranosidase. Many of them are able to split more than one substrate. Fructans hydrolases were proposed to classify into three types, including patterns of their action: levanhydrolases (levanases), inulinhydrolases (inulinase), hydrolases of other fructans. It is known that fructose and glucose are the products of hydrolysis reactions [5]. In the literature there are many data due to the properties of rumen bacteria fructanhydrolases, but still their activity and kinetic parameters for clinoptilolite influence that determined the purpose of our work have not been investigated.

\section{Materials and methods}

The research was carried out on cell-free extracts of rumen bacteria of rams which over twenty-one days were fed with natural fructane and sorbent clinoptilolite. Manipulation of animals were carried out in compliance with "European Convention for the Protection of Vertebrate Animals, which are used for experimental and other scientific purposes" (Strasbourg, 1986), the Decisions of the first National Congress on Bioethics (Kyiv, 2001) and the Law of Ukraine "On protection of animals from maltreatment" (Kyiv, 2006).

To obtain mixed microbial populations freshly taken from cicatricial rams fluid was filtered through a nylon fabric to remove large remnants of feed, added twin- 80 to a final concentration of $0.2 \%$. This surface-active agent was used to release microorganisms that are closely connected with the feed particles. In such condition rumen contents were kept at room temperature for one hour. Sedimentary fraction containing bacteria was obtained from rumen fluid by the method of differential centrifugation by the method which has been described [6].

Mixed population bacteria were collected by centrifugation at $6000 \mathrm{rpm}$ for $30 \mathrm{~min}\left(4^{\circ} \mathrm{C}\right)$, then they were washed twice with $20 \mathrm{mM} \mathrm{K-Na-}$ phosphate buffer ( $\mathrm{pH}$ 7.5). The concentration of cells was adjusted to $1 \mathrm{mg} / \mathrm{ml}$ and frozen. They were added to a suspension of the third volume of glass sand and carried out the destruction of celis in the ice using a planetary vibrator K-23 (FRG) for 1,000 rpm for 6 minutes. Cells remains were precipitated by centrifugation at $18,000 \mathrm{rpm}$ for 30 minutes in the ice [7].

The unit of inulinase activity had the amount of enzyme, that catalyzes the formation of $1 \mathrm{mM}$ of fructose from inulin for 1 minute in standard conditions $\left(\mathrm{t}=50^{\circ} \mathrm{C}, \mathrm{pH} 4.6\right)[8,9]$. Kinetic analysis of fructane hydrolysis reaction by inulinase was performed in a standard incubation environment, which was modified by the physicalchemical parameters (temperature, $\mathrm{pH}$ ) and substrates content. The Michaelis constant $\left(\mathrm{K}_{\mathrm{m}}\right)$ was defined under substrate saturation (inulin and levan) and a maximum speed of hydrolysis $\left(\mathrm{V}_{\max }\right)$ by the method of Laynuyivera-Berk. The equation of a linear function that best approximates the experimental data, The equation of a linear function that best approximates the experimental data, were calculated using the least squares method $[10,11]$. The activity of levanase was determined in a standard environment, which contained $0.5 \mathrm{ml}$ of $0.2 \%$ of levan in $20 \mathrm{mM}$ of phosphate buffer (pH 6.0) and $0.5 \mathrm{ml}$, respectively dilute solution of rumen extract. To determine a possible inulin metabolism, levan was replaced on inulin in a standard environment. The reaction mixture was incubated at $37^{\circ} \mathrm{C}$ for $60 \mathrm{~min}$, after which was boiling in water bath for 3 minutes.

The total content of reducing sugars released after incubation was measured by the method [12]. The kinetic analysis of the hydrolysis reaction of levan by levanase was conducted by a similar scheme to inulinase, but in experiments with sorbent only levan was used. The coefficient of Student was calculated to evaluate the probable difference between the statistical characteristics of alternative information of data. Plausible difference in terms of probability $\mathrm{P}<0.05-0.001$ [13] was considered.

\section{Results and discussion}

It was found that on the second day of the experiment inulinase activity is increased in 5 times in conditions of inulin action, compared with the control group (fig. 1A). This activity has increased by $17 \%$ for fourteen days, and after the cessation of inulin feeding dropped sharply to almost control 
values. Under the influence of sorbent the inulinase activity increased at $18-30 \%$ during the whole period of feeding. It is known that this enzyme is also able to hydrolyze raffinose, sucrose and levan [12-15]. The activity of inulinase under the conditions of levan feeding on the second day was twice greater, compared to control and increased on the $7^{\text {th }}, 17^{\text {th }} 21^{\text {st }}$ days. An enzyme activity was increased by $10-31 \%$ in the presence of sorbent in feed (fig. 1B). It is obvious that because of the large size of the levan molecule, its hydrolysis was less intense compared to inulin.

The kinetic analysis of insulin splitting and levan by inulinase on animals with rumen bacteria on the $14^{\text {th }}$ day of fructans feeding and their mixtures with clinoptilolites sorbent was
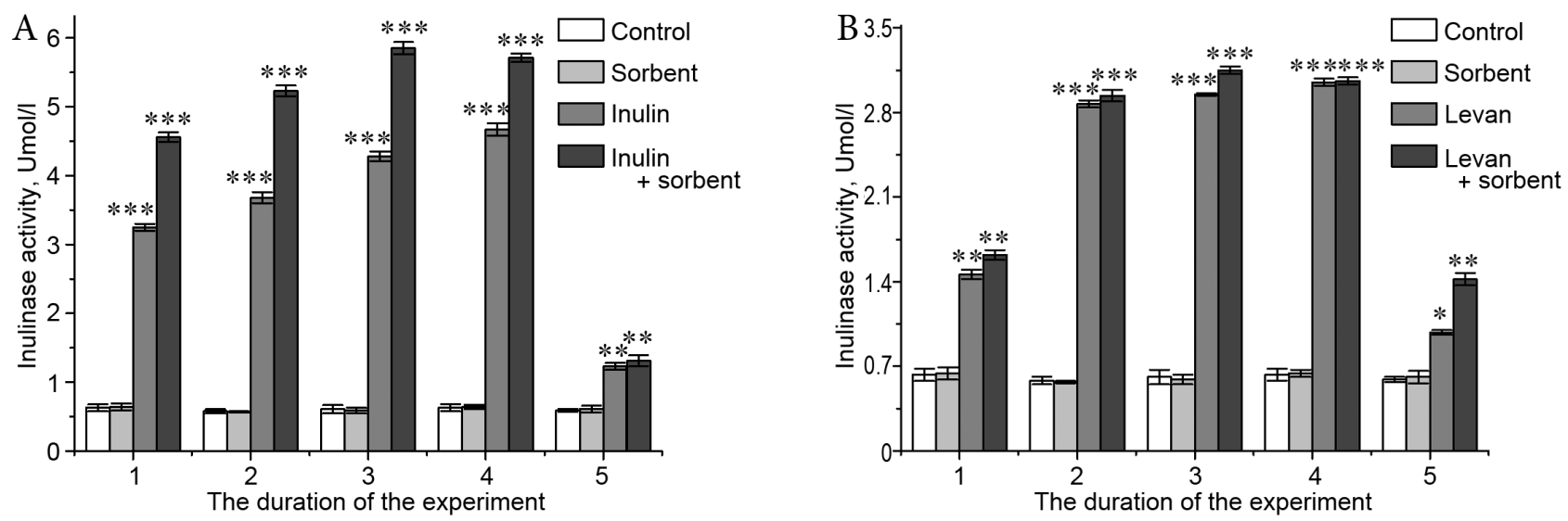

Fig. 1. Inulinase activity of the rumen of animals during feeding with inulin (A), levan (B) and sorbent during two (1); seven (2); fourteen (3); twenty-one days (4); and also ten days after the cessation of feeding (5)
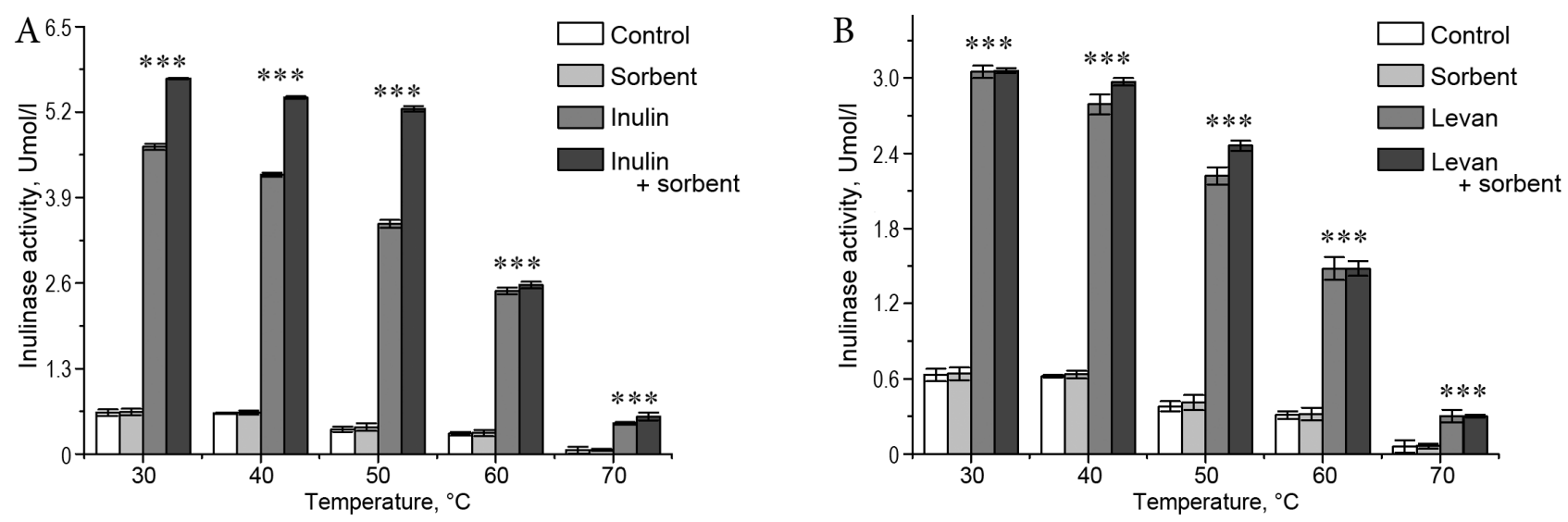

Fig. 2. The temperature optimum of inulinase activity of rumen bacteria under conditions of fermentation of inulin (A), levan (B) and sorbent
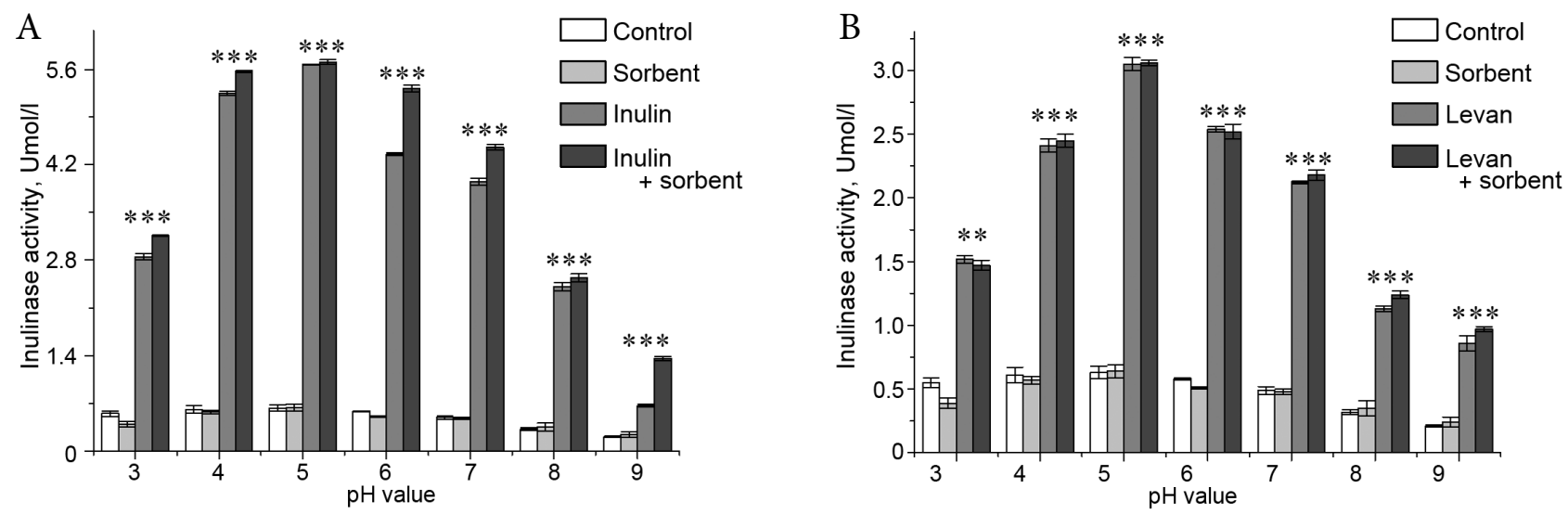

Fig. 3. Effect of $\mathrm{pH}$ on inulinase activity of rumen bacteria by metabolism of inulin (A), levan (B) and sorbent 
completed. Temperature optimum of enzyme activity was established. In particular, the peak of inulinase activity was observed at a temperature of $37{ }^{\circ} \mathrm{C}$ in the control and experimental groups of animals. The presence of sorbent in feed stipulated the increased activity of the enzyme. With further increasing of temperature the activity was decreased, but it was registered even at $70{ }^{\circ} \mathrm{C}$, indicating a significant thermal stability of investigational enzyme (fig. 2A, B).

The effect of $\mathrm{pH}$ on incubation medium on inulinase activity of rumen bacteria was determined. A typical dome-shaped dependence with an optimum value of 5 , but under the influence of inulin and its mixture with sorbent of highly activity was also noted in 4 (fig. 3A, B). These data are consistent with the results of searches in vitro, which shows that in the fermentation of this fructan $\mathrm{pH}$ medium was decreased to 4 .

The kinetic analysis of the cleavage reaction of fructans was performed depending on

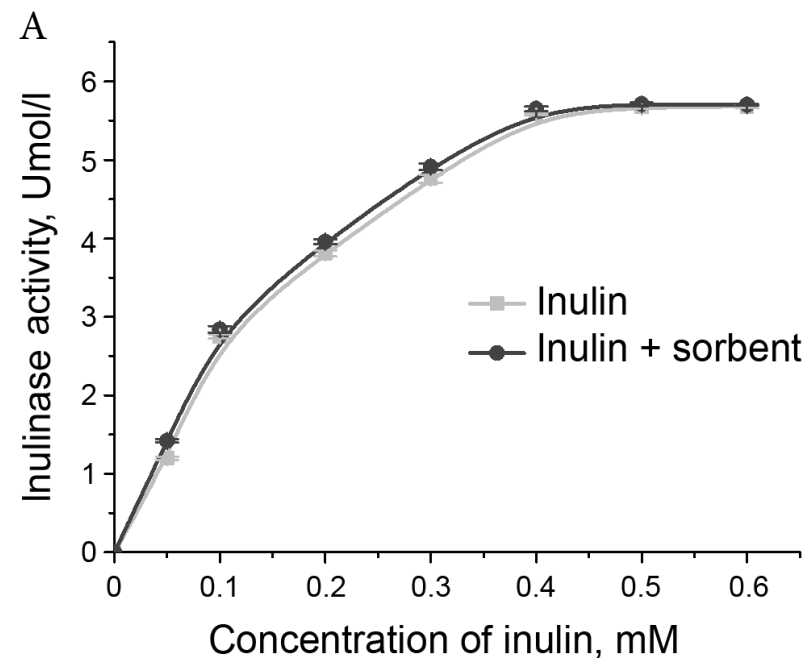

their concentration in the incubation medium on the next stage. We found out that increasing concentration as inulin and levan from 0.1 to $0.4 \mathrm{~mm}$ monotonous increase of enzymatic inulinase activity to its maximum value was occurred, after which the activity was maintained at a constant level (plateau on the graph). The presence of sorbent in feed does not affect on the saturation of enzyme by the substrate (fig. 4A, B).

To elucidate the possible changes mechanism of the inulin activity under conditions of levan metabolism, inulin and their mixture of sorbent it was calculated some kinetic parameters of the reaction by the effect of different concentrations of the substrate, such as maximum speed $\left(\mathrm{V}_{\max }\right)$ and Michaelis constant $\left(\mathrm{K}_{\mathrm{m}}\right)$. Their determination was done as a result of receiving linear function (linearization) data in coordinates Laynuyiver-Berke (fig. 5A, B). So, $\mathrm{V}_{\text {max }}$ under the conditions of levan splitting increased by 4 times compared with the control, and the inulin -17 times (table 1).

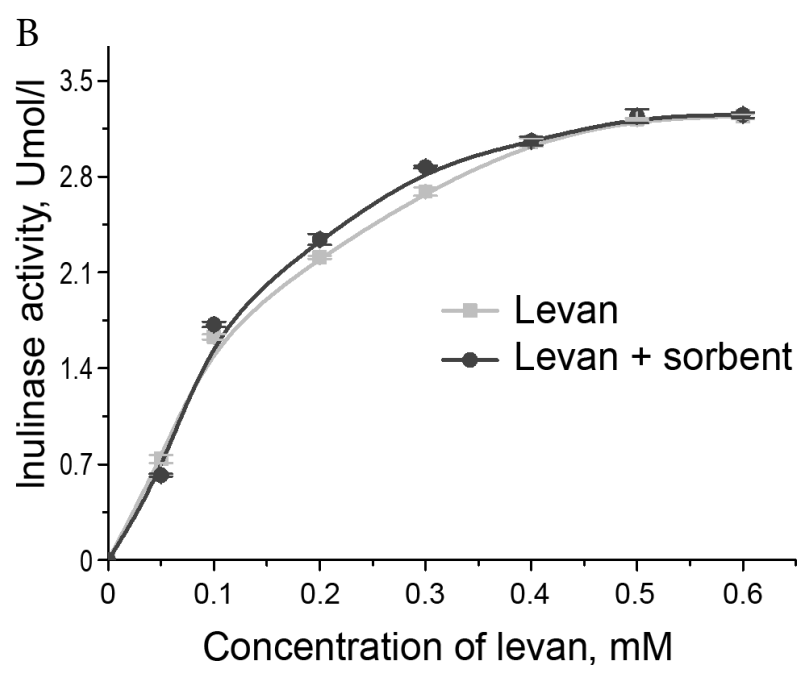

Fig. 4. Influence of the substrate in various concentrations on the activity of rumen bacteria inulinase on inulin metabolism (A), levan (B) and sorbent
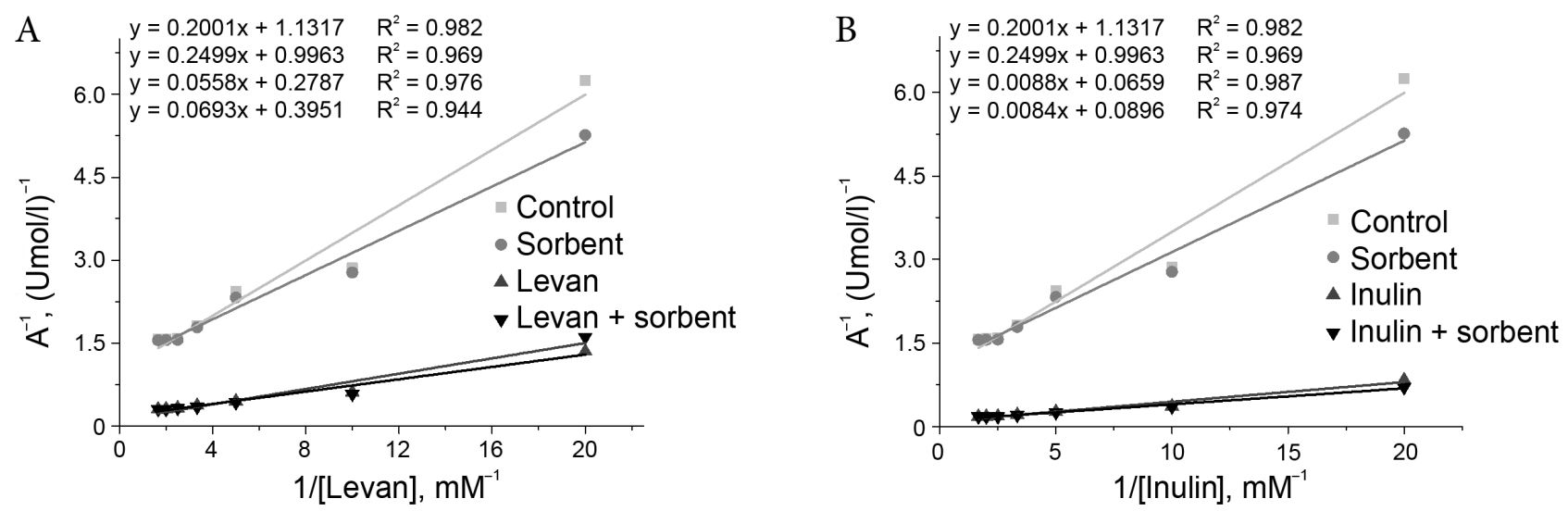

Fig. 5. Linearization of curves inulinase activity for the metabolism of fructans in coordinates of Laynuyivera-Berke 

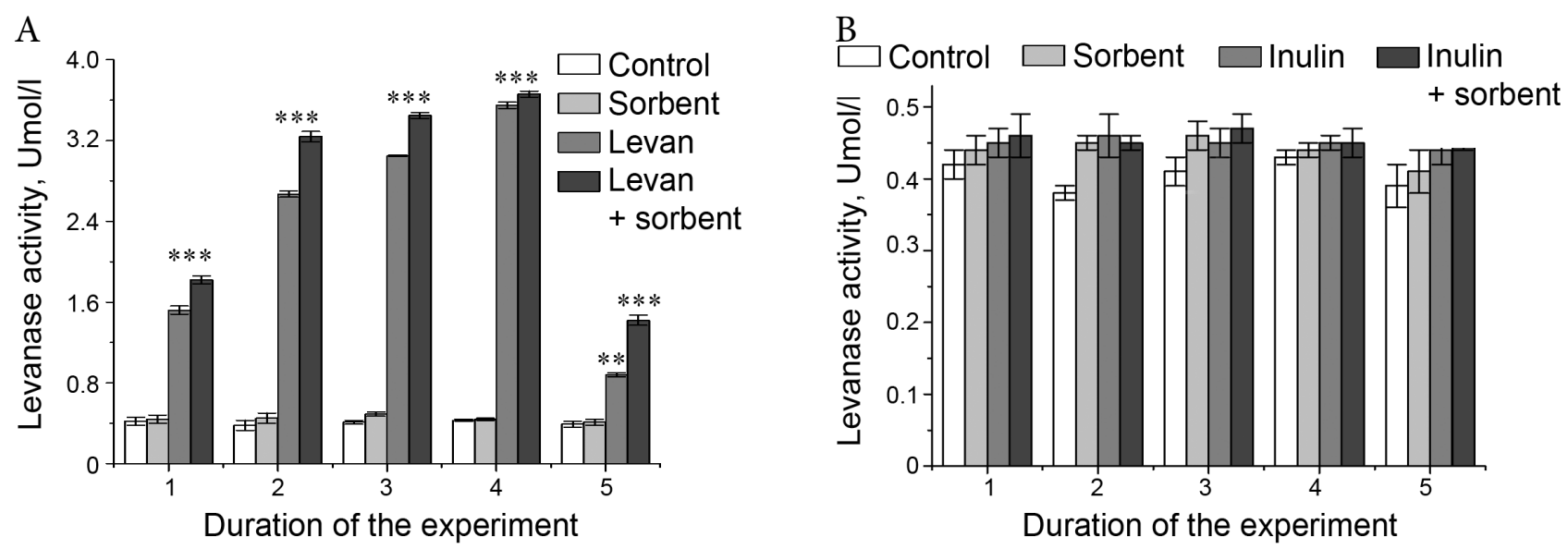

Fig. 6. Levanase activity of rumen bacteria when feeding with levan (A), inulin (B) and sorbent for two (1); seven (2); fourteen (3); twenty-one days (4); and also ten days after the cessation of feeding (5)
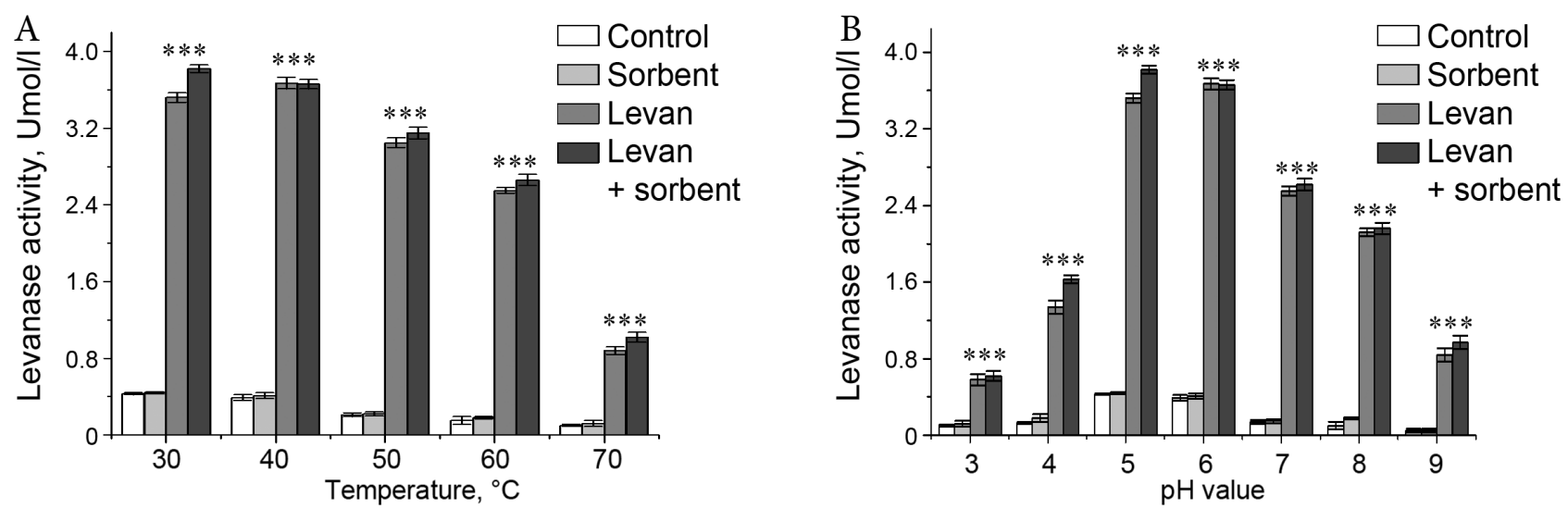

Fig. 7. Temperature (A) and $\mathrm{pH}(\mathrm{B})$ optimum levanase activity of rumen bacteria under conditions of fermentation of levan and sorbent
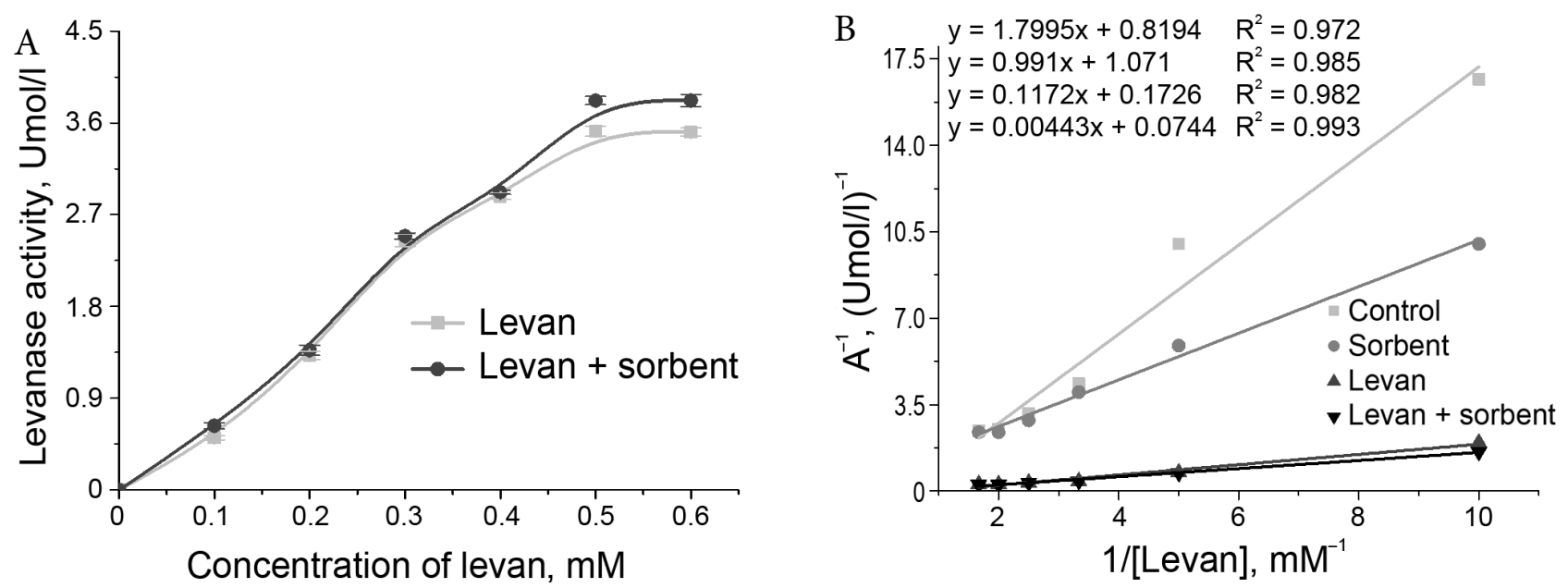

Fig. 8. The influence of the substrate on the activity of levanase (A),

linearization of curves in coordinates of Laynuyivera-Berke (B), by levan metabolism of rumen bacteria

The presence of sorbent leads to a significant increase in this parameter compared to control, and its mixture of fructan, on the contrary - to decrease, compared with the environment only with fructan. That is the inulin cleavage occurs more rapidly than levan if the enzyme is completely saturated with substrate.

Michaelis constant defines the affinity of the enzyme to the substrate, and in the inverse dependence $[16,17] . \mathrm{K}_{\mathrm{m}}$ value was increased by le- 
The results of kinetic analysis of fructans cleavage

\begin{tabular}{|c|c|c|c|c|c|c|}
\hline Kinetic parameters & Control & Sorbent & Levan & $\begin{array}{c}\text { Levan }+ \\
\text { Sorbent }\end{array}$ & Inulin & $\begin{array}{c}\text { Inulin }+ \\
\text { Sorbent }\end{array}$ \\
\hline $\mathrm{V}_{\max }\left(\mathrm{mcmol}\right.$ fructose $/ \mathrm{min} \times \mathrm{mg}^{-1}$ protein $)$ & 0.88 & 1.00 & $3.58^{* * *}$ & $2.53^{* * *}$ & $15.17^{* * *}$ & $11.16^{* * *}$ \\
\hline $\mathrm{K}_{\mathrm{m}}(\mathrm{mmol} / \mathrm{l})$ & 0.17 & 0.25 & 0.20 & 0.17 & 0.13 & $0.09^{*}$ \\
\hline
\end{tabular}

Table 2

The results of kinetic analysis of levan cleavage

\begin{tabular}{|c|c|c|c|c|}
\hline Kinetic parameters & Control & Sorbent & Levan & Levan + Sorbent \\
\hline $\mathrm{V}_{\max }\left(\mathrm{mcmol}\right.$ fructose $/ \mathrm{min} \times \mathrm{mg}^{-1}$ protein $)$ & 1.22 & 0.93 & $5.79^{* * *}$ & $13.44^{* * *}$ \\
\hline $\mathrm{K}_{\mathrm{m}}(\mathrm{mmol} / \mathrm{l})$ & 2.19 & $0.92^{* *}$ & $0.67^{* * *}$ & $0.59^{* * *}$ \\
\hline
\end{tabular}

van metabolism by $13 \%$ and decreased by inulin metabolism - $24 \%$, compared with the control. This information confirms that the investigational enzyme has a higher affinity for inulin compared with levan (table 1).

It was studied the activity of levanase in extracellular extract of animal rumen, which within twenty-one days natural fruit and clinoptilolite were added to the feed, and also in ten days after the cessation of feeding. We observed the increased activity of search enzyme in 4-8 times, compared with the control, while feeding the animals with levan, within 21 days. Through ten days after the cessation of feeding the activity was decreased and was twice more than the control value. In the presence of sorbent in the feed, levanase activity was increasing throughout the period of feeding by $12-18 \%$, compared to animals that did not consume (fig. 6). We determined levanaze activity in rumen fluid of animals to which as a part of the basic diet was added inulin and its mixture with clinoptilolite. Still, the enzyme activity did not differ from controls (fig. 6B). This confirms the assumption that levanaze is not able to hydrolyze inulin.

Kinetic analysis was done and kinetic parameters were calculated $\left(\mathrm{V}_{\text {max }}\right.$ and $\mathrm{K}_{\mathrm{m}}$ ) hydrolysis reaction of levan by levanase bacteria of rumen. Optimum enzyme temperature was $30-40{ }^{\circ} \mathrm{C}$, but the activity remained at $70{ }^{\circ} \mathrm{C}$ (fig. 7A). The enzyme did not lose the activity at different $\mathrm{pH}$ values - from 3 to 9 , but most noted for 5-6 (fig. 7B). Clinoptilolite did not show significant effect on the levanase activity for the investigated conditions.

The saturation of the enzyme substrate was occurred in the presence of $0.5 \mathrm{mM}$ of levan in the medium and was not changed under the influence of sorbent (fig. 8A).

This value was increasing by the levan cleavage into 5 times compared to the control. However, $\mathrm{K}_{\mathrm{m}}$ value was decreased by levan metabolism to $69 \%$ compared to control, which indicates the increase affinity of the enzyme to the substrate. In the presence of sorbent the affinity is also increased (table 2).

\section{Conclusions}

So, as a result of inulin and levan feeding to ram during 21 days it takes place their plitting with inulinase and levanase of proventriculus bacteria. It was defined the temperature and $\mathrm{pH}$ optimum activity of these enzymes. Inulin is metabolized by inulinase at a higher rate compared to levan, under conditions of saturation with the substrate. Levanase hydrolyzes levan, but is inactive due to inulin. The saturation of enzyme substrate does not depend on the nature fructane. However the affinity of inulinase to inulin is higher compared to the levan. In the presence of clinoptilolite the affinity to both hydrolase to substrates is increasing.

Perspective for further research. It is planned to study metabolic processes of fructanes on the processes of oxidative stress in the organisms of farm animals.

1. Baran M., Kravtsiv R., Kalachnyuk G., Bomba A., Zitnan R. Optimisation of ruminant digestion by influencing the ruminal fermentation. Slov. Vet. J., 2008, no. 2, pp. 117-118. (in Ukrainian)

2. Ettalibi M., Baratti J. C. Molecular and kinetic properties of Aspergillus ficuum inulinases. Agric. Biol. Chem., 1990, Vol. 54, pp. 61-66. 
3. Dai D., Nanthkumar N. N., Newburg D. S., Walker W. A. Role of oligosaccharides and glycoconjugates in intestinal host defense. Journal of Pediatric Gastroenterology and Nutrition, 2000, vol. 30, no. 2, pp. 23-33. $116 \mathrm{p}$.

4. Safety evaluation of fructan. Tema Nord, 2000,

5. Wanker E., Huber A., Schwab H. Purification and characterization of the Bacillus subtilis levanase produced in Escherichia coli. Applied and Environmental Microbiology, 1995, Vol. 61, no. 5., pp. 1953-1958.

6. Alijev A. A., Kafarov M. S. The method of fractionation of proventriculus contents on components. Bull. farm animals, 1971, V. 5, pp. 69-72.

7. Vlizlo V. V., Fedoruk R. S., Ratych I. B. Laboratory methods of research in biology, animal husbandry and veterinary medicine. A guide. Lviv, Spolom, 2012, 764 p. (in Ukrainian)

8. Eisenberg V. L., Stojko V. I., Demidenok E. A. Methods of quantitative determination of the activity of the fungal inulinase using Sumner reagent. Biotechnology, 2007, no. 5, pp. 95-96. (in Russian)

9. Avigad G., Bauer S. Fructan hydrolase. Methods Enzymol., 1966, Vol. 8, pp. 621-628.

10. Cornish-Bowden A. Fundamentals of Enzyme Kinetics. $4^{\text {th }}$ Edition. 2012, 510 p.
11. Wilkinson G. N. Statistical estimations in enzyme kinetics. Biochem. J., 1961, Vol. 80, p. 32.

12. Somogyi M. Notes on sugar determination. J. Biol. Chem., 1952, Vol. 195, pp. 19-23.

13. Stryer L. Biochemistry. W. H. Freeman \& Co, New York, 1988.

14. Antosova M., Polakovic M Fructosyltransferases: the enzymes catalyzing production of fructooligosaccharides. Chem. Pap. - Chem. Zvesti, 2001, Vol. 55, pp. 350-358.

15. Farine S., Versluis C., Bonnici P. J. Application of high performance anion exchange chromatography to study invertase-catalysed hydrolysis of sucrose and formation of intermediate fructan products. Appl. Microbiol. Biotechnol., 2001, Vol. 55, pp. 55-60.

16. Pudjono G., Barwald G., Amanu S. Activity of inulinase of some strains of Bifidobacter iumand their effects on the consumption of foods containing inulin and other fructans. Inulin and inulin-containing crops. Amsterdam, Elsevier, 1993, pp. 373-379.

17. Muramatsu K., Onodera S., Kikuchi M., Shio$\mathrm{miN}$. Substrate specificity and subsite affinities offructofuranosidase from Bifidobacterium adolescentis G1. Biosci Biotechnol Biochem., 1994, Vol. 58, pp. 1642-1645. 